\title{
Efficacy of a community-based dietary intervention to enhance micronutrient adequacy of high-phytate maize-based diets of rural Malawian children
}

\author{
Fiona Yeudall ${ }^{1}$, Rosalind S Gibson ${ }^{1, *}$, Timothy R Cullinan ${ }^{2}{ }^{\prime} \dagger$ and Beatrice Mtimuni ${ }^{3}$ \\ 'Department of Human Nutrition, University of Otago, Union Street, PO Box 56, Dunedin 9015, New Zealand: \\ ${ }^{2}$ Department of Community Health, College of Medicine, Blantyre, University of Malawi, Lilongwe, Malawi: ${ }^{3}$ Bunda \\ College of Agriculture, University of Malawi, Lilongwe, Malawi
}

Submitted 13 August 2001: Accepted 18 April 2005ł

\begin{abstract}
Objective: To evaluate the efficacy of a community-based dietary intervention to reduce risk of micronutrient inadequacies in high-phytate maize-based Malawian diets.

Design: Quasi-experimental post-test design with a non-equivalent control group.

Setting: Four villages in Mangochi District, Southern Malawi.

Participants: Households with children aged $3-7$ years in two intervention $(n=200)$ and two control $(n=81)$ villages participated in a 6-month intervention employing dietary diversification, changes in food selection patterns, and modifications to food processing to reduce the phytate content of maize-based diets. Baseline comparability between the groups was confirmed via assessment of sociodemographic characteristics, anthropometry, knowledge and practices, morbidity, haemoglobin and hair zinc. After 12 months, knowledge and practices and dietary intakes were assessed by interactive 24-hour recalls, one during the food plenty and a second during the food shortage season. Nutrient adequacy for the two groups was compared via dietary quality indicators and predicted prevalence of inadequate intakes using the probability approach.

Results: Intervention children had diets that were significantly more diverse and of a higher quality than those of controls. Median daily intakes of protein, calcium, zinc (total and available), haem iron, vitamin $\mathrm{B}_{12}$ and animal foods (grams; \% of total energy) were higher $(P<0.05)$ whereas phytate intakes, phytate/zinc and phytate/iron molar ratios were lower $(P<0.01)$ in the intervention group; some spread of knowledge and practices to controls occurred.

Conclusions: Our community-based dietary strategies reduced the predicted prevalence of inadequate intakes of protein, calcium, zinc and vitamin $\mathrm{B}_{12}$, but not iron, in children from Malawian households with very limited resources.
\end{abstract}

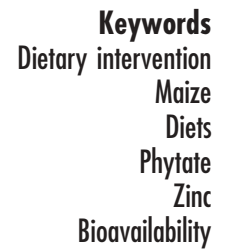

The existence of multiple micronutrient inadequacies in the plant-based diets of children in developing countries and their aetiological role in childhood stunting have gained increasing recognition ${ }^{1-5}$. As a result, several trials involving multiple micronutrient supplements or fortificants have been conducted in developing countries. In general, results have been disappointing. In some cases, no effect of multi-micronutrients on growth was seen ${ }^{4,6-9}$, whereas in others the actual increase in linear growth in children receiving the multi-micronutrients, when observed, has been less than the potential increment expected $^{4,10}$. These mixed results have highlighted the constraints on growth in children in developing regions, imposed by prenatal and/or intergenerational maternal malnutrition ${ }^{11}$, and emphasise the critical need for sustainable dietary interventions to improve the micronutrient adequacy of plant-based diets across generations in developing countries.

Supplementation with multi-micronutrients is not a sustainable solution over the long term for alleviating micronutrient malnutrition on a national basis. It relies on a stable infrastructure and requires financial support on along-standing sound economic basis. A preferred 
approach for achieving a more sustained impact is to use dietary strategies designed to enhance the quantity and bioavailability of multiple micronutrients in plant-based diets. Such an approach can be adapted to local conditions so that it is affordable and requires no external support. It has the added advantage of being community-based, so that it can be used to enhance the awareness of micronutrient malnutrition as well as to empower the community to become more self-reliant ${ }^{12}$.

We have developed a unique food-based intervention for use in countries where staple diets are maize-based, such as rural Southern Malawi, based on our earlier Malawian dietary studies ${ }^{13-18}$. Our intervention employed dietary diversification and traditional household methods for preparing and processing indigenous foods ${ }^{19}$. Specifically, our dietary strategies involved:

1. Increasing production and consumption of micronutrient-dense foods including orange-red fruits such as papayas and mangoes (fresh and dried) and flesh foods, especially whole dried fish with bones;

2. Incorporating absorption enhancers of iron, zinc, provitamin A carotenoids and vitamin A in household diets; and

3. Employing germination, fermentation and soaking to reduce the phytate content of maize and/or legumes by enzyme-induced hydrolysis of phytate and/or passive diffusion of water-soluble phytate ${ }^{19}$.

To our knowledge, this is the first community-based trial that has incorporated household methods designed specifically to reduce the phytate content of maize-based diets with the aim of enhancing the bioavailability of zinc, non-haem iron and calcium. Our strategies were implemented using a participatory approach to enhance awareness, sustainability, feasibility and acceptability to caregivers in the local community. On-going nutrition education and community mobilisation techniques were utilised to enhance adoption of the dietary strategies and to empower the community to sustain them. Details of these dietary strategies and their implementation have been published earlier ${ }^{20}$.

In the present work we assessed the efficacy of our dietary diversification/modification on enhancing the content and bioavailability of micronutrients in the diets of Malawian children aged 3-7 years using a quasiexperimental post-test design. This was achieved by comparing the nutrient adequacy of the diets of children from households receiving the 6-month dietary intervention with that of a comparable group who consumed their habitual maize-based diets over the same period. Nutrient adequacy was assessed after 12 months by comparing dietary quality and risk of inadequate nutrient intakes in the intervention and control groups ${ }^{21}$. Nutrition knowledge and practices related to the preparation and consumption of micronutrient-rich foods were also assessed.

\section{Study population and survey design}

A participatory approach focusing on building relationships and community involvement was utilised to enhance participation and sustainability. Details have been published elsewhere ${ }^{20}$. Villages were selected by an advisory committee, in keeping with this participatory approach, based on perceived need and similar socioeconomic and food production characteristics (primarily access to fish). Ministry staff working in all four communities were among the advisory committee members. The community group leaders chose the project name 'Tulimbe', which means 'let us be strong', because it embodies the idea of empowerment or self-reliance. Children aged 3 to 7 years were chosen as the target group because they are no longer being breast-fed ${ }^{22}$ and consume a high-phytate diet in which more than $50 \%$ of energy is from maize ${ }^{15}$. Therefore, our phytate reduction strategies had the potential to enhance the bioavailability of iron, zinc and calcium in these rural children's diets.

A census was undertaken to identify households with children born between 1989 and 1993 in two intervention and two control villages in Mangochi District in Southern Malawi. No attempt was made to select a random sample of children because this approach was not acceptable to the advisory committee. Of the 471 households for whom sociodemographic data were collected, 412 were confirmed to have children born between 1989 and 1993, who were apparently healthy and thus eligible for the study. No significant sociodemographic differences existed between eligible and non-eligible households, with the exception of household size. Children for whom accurate birth dates were not available were excluded from the final analysis $(n=42)$.

The study was approved by the Health Sciences Research Committee, University of Malawi and the University of Otago Human Ethics Committee, New Zealand. Verbal consent was obtained from the traditional village authorities and from primary caregivers of the children after the nature of the study had been fully explained to them. Control communities were provided with the intervention at the end of the post-intervention data collection period (see Fig. 1). A quasi-experimental post-test design was used for assessing the efficacy of the dietary strategies because baseline nutrient intake data for the two groups were not available.

\section{Methods}

All children were treated with anthelmintic medication (albendazole) at baseline and, when necessary, at monthly clinics beginning in December 1996. Baseline comparability between the intervention $(n=200)$ and control $(n=81)$ groups was assessed via sociodemographic status, knowledge and practices, anthropometry, haemoglobin and hair zinc status (Tables 1 to 3). Women were 


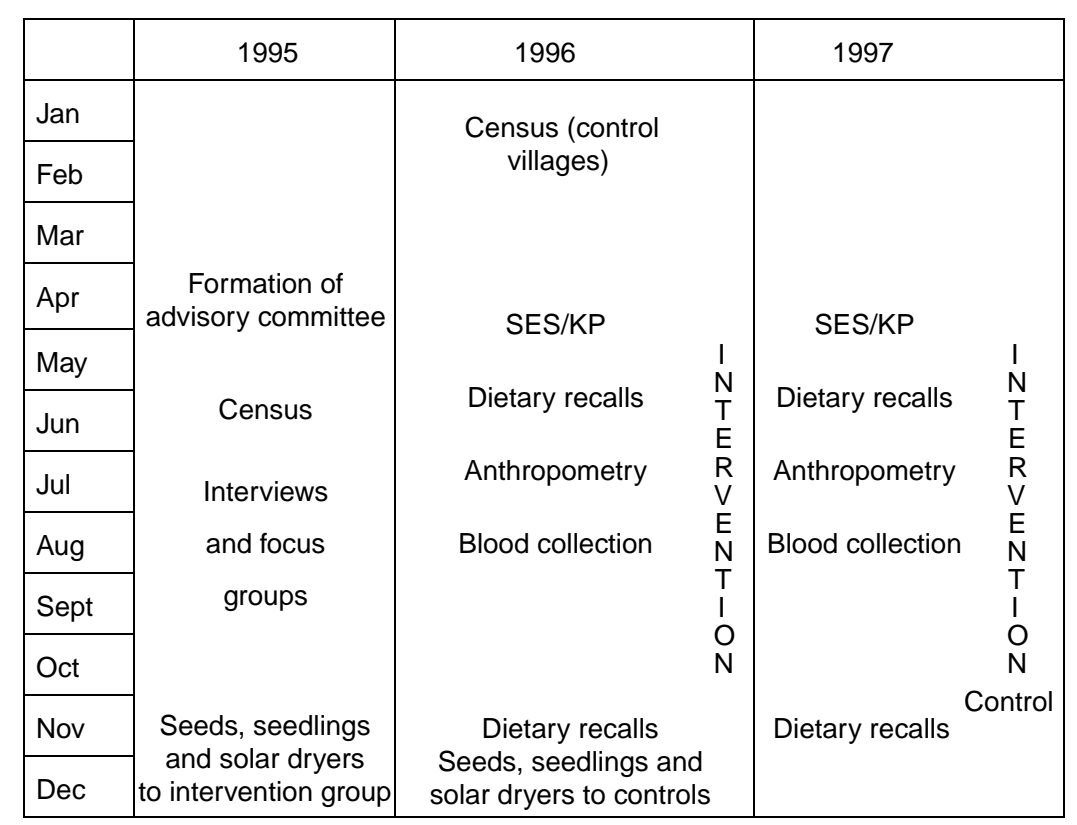

Fig. 1 Project timeline (SES - socio-economic status; KP - knowledge and practices)

the primary respondents as they are generally the de facto heads of household ${ }^{23}$. Details of the anthropometry and biochemical assessment are published elsewhere ${ }^{24}$. The dietary strategies were implemented over 6 months from June to November 1996, and post-intervention differences between groups assessed 12 months after baseline data collection (Fig. 1).

\section{Assessment of general bealth, demographic and socio-economic status, and food production characteristics}

Data on sociodemographic and sanitation characteristics were collected at baseline by personal household interviews and repeated observations using a pre-tested questionnaire, described earlier ${ }^{17}$. A component on food production characteristics, derived from a Malawi National Monitoring Initiative, was also included. All interviews were conducted by trained research assistants who were fluent in the local language (Yao) and English.

\section{Assessment of knowledge and practices}

The knowledge and practices (KP) questionnaire was developed from earlier questionnaires ${ }^{25}$, and interviews and focus groups conducted in the study communities ${ }^{26}$. After pre-testing, the KP questionnaire was administered in the households using an open-ended format. Zinc per se was not named in the nutrition education messages because, unlike iron and vitamin A, zinc was not included in national nutrition education strategies in Malawi. Only the 310 (75\%) households completing the KP questionnaire at baseline and at 1 year are included in the analyses (Tables 3 and 4).

\section{Assessment of food consumption patterns and nutrient intakes}

Dietary data were collected in the households from one child per household post intervention using two interactive 24-hour recalls, one during the post-harvest food plenty (June 1997) and the second during the preharvest food shortage season (November 1997). Each day of the week was equally represented in both seasons. Of 412 eligible households, 371 (90\%) participated in June and $352(85 \%)$ in November; recall results are presented for children who participated in both seasons (i.e. 68\%). Response rates did not differ between groups. Mothers were the primary surrogate respondents for the children's food intake.

Details of our validated 24-hour recall procedure and the strategies employed to reduce memory lapses and enhance the accuracy of portion size estimates have been described earlier ${ }^{13,18,27}$. Mothers were instructed not to change the dietary patterns of their children over the recall days.

Conversion factors for gram weight equivalents from portion size estimates and ingredients for mixed dishes were calculated when required from average weights of edible portions of foods collected from households and local merchants ${ }^{27}$. For some mixed dishes, average recipes compiled by Ferguson et al. ${ }^{15}$ and Hotz ${ }^{28}$ were used.

Average daily intakes and major food sources of nutrients (including available iron and zinc) and antinutrients were calculated by meal using the WorldFood Dietary Assessment System 2.0 29 , a Malawi food composition database derived from analysed trace element and phytate values ${ }^{30}$ and the International Minilist nutrient database ${ }^{29}$. Observed protein intakes were adjusted to utilisable protein intakes ${ }^{29}$. A food diversity 
score was also calculated based on the average number of unique food items eaten, with the exception of water, discretionary sugar and tea ${ }^{31}$. Foods and beverages were classified into the 10 major groups itemised in Table 5; intake of fats and oils was negligible.

Intakes of phytate from maize-based staples were adjusted for children from households reportedly using phytate-reducing practices in the post-intervention KP survey. Adjustments were based on a $50 \%$ reduction in the average hexa- and penta-inositol phosphate content of nsima (stiff maize-based porridge) and phalas (thin maize-based porridge) prepared from soaked and fermented unrefined white maize flour, as reported by laboratory studies of Hotz and Gibson ${ }^{32}$. The predicted prevalence of inadequate intakes was calculated for selected nutrients using the probability approach ${ }^{21}$ and estimated mean requirements ${ }^{33-36}$, compiled by Bunch and Murphy ${ }^{29}$.

\section{Statistical analysis}

Statistical analyses were performed by SPSS $^{37}$ version 8.0. All continuous variables were examined for normality. Results are expressed as median (interquartile range) for consistency due to non-normal distributions of several nutrient intakes. Differences between intervention and control groups were assessed by the Kruskal-Wallis or Pearson chi-square test, where appropriate. Comparison of differences in proportions within groups over time was assessed by the McNemar test. Statistical significance was set at $P \leq 0.05$.

\section{Results}

Baseline height and weight, as $Z$-scores for height-for-age (HAZ) and weight-for-height (WHZ), haemoglobin and hair zinc were compared between participants in the 1 -year post intervention and drop-outs. No significant differences existed, suggesting that participation was random and not linked to differences in anthropometric or biochemical status.
Comparison of demographic and socio-economic status, and food production characteristics

Table 1 presents baseline age, sex, growth, hair zinc and haemoglobin data; no differences existed, except that the intervention children were significantly younger than the controls. Likewise, no differences for household size, number of children and sex of head of household $(\mathrm{HOH})$ were apparent (Table 2). Although HOHs in both groups were mainly subsistence farmers, intervention $\mathrm{HOHs}$ were more involved in other income-generating activities than the control HOHs. In the intervention households, more HOHs (female and male combined) and mothers had no formal education than controls $(P<0.01)$. House quality was assessed as a proxy for income status. Most households lived in houses made of sun-dried brick with thatched roofs and no windows (i.e. with a house quality score of zero), and had pit latrines (Table 2). Household food production characteristics were similar: about 50\% in each group owned livestock and had an off-season garden.

\section{Comparison of reported knowledge and practices}

There were no significant differences in knowledge or practices between groups at baseline. In contrast, after 1 year, intervention parents had a greater knowledge of iron (60 vs. $8 \%, P<0.001)$, vitamin A ( 84 vs. $74 \%, P<0.05)$ and food sources of iron (50 vs. 36\%, $P<0.05$ ), and reportedly practised fermentation of maize-flour more $(56$ vs. $1 \%, P<0.001$ ), than the parents of controls (Tables 3 and 4 ). No other differences in practices existed at 1 year, attributed to a significant increase in knowledge and practices within both groups (Table 4).

\section{Comparison offood consumption patterns, nutrient intakes and indicators of dietary quality}

The contributions of food groups post intervention are expressed in $\mathrm{gday}^{-1}$ (Table 5) and as percentage of energy intake (Fig. 2). Although intakes of maize-based staples were similar (Table 5), they contributed a smaller proportion of energy for intervention than for control diets (55 vs. $60 \%, P=0.001$; Fig. 2 ), especially the traditional

Table 1 Baseline age, growth, hair zinc and haemoglobin variables* for the intervention and control groups

\begin{tabular}{|c|c|c|c|}
\hline & Intervention & Control & $P$ treatment $\dagger$ \\
\hline Age (months) & $68(65,70)$ & $74(70,78)$ & 0.016 \\
\hline Percentage boys & 52 & 49 & 0.678 \\
\hline $\mathrm{HAZ}$ & $-1.76(-1.98,-1.53)$ & $-1.91(-2.25,-1.57)$ & 0.455 \\
\hline WHZ & $0.04(-0.10,0.19)$ & $0.03(-0.18,0.24)$ & 0.940 \\
\hline Maternal height (cm) & $154.9(154.0,155.9)$ & $153.7(152.3,155.1)$ & 0.150 \\
\hline Hair Zn $\left(\mu \mathrm{mol} \mathrm{g}^{-1}\right)$ & $182.5(176.6,188.4)$ & $177.5(168.2,186.7)$ & 0.370 \\
\hline Haemoglobin $\left(\mathrm{gl}^{-1}\right)$ & $10.9(10.6,11.1)$ & $10.9(10.5,11.3)$ & 0.828 \\
\hline
\end{tabular}

HAZ - height-for-age Z-score; WHZ - weight-for-height Z-score.

${ }^{*}$ Data are expressed as median (first, third quartile).

†Test for significance of differences in \% males by Pearson chi-square test. Other differences assessed by conventional multiple analysis of variance techniques using treatment and sex as independent variables and age as a covariate. 
Table 2 Baseline sociodemographic, house quality and sanitation data* for the intervention and control groups

\begin{tabular}{|c|c|c|c|}
\hline & Intervention & Control & $P$ treatment $\dagger$ \\
\hline Household size & $5.1(4.9,5.3)$ & $5.4(5.0,5.7)$ & 0.132 \\
\hline $\begin{array}{l}\text { No. of children per } \\
\text { household }\end{array}$ & $3.0(2.9,3.2)$ & $3.2(2.9,3.5)$ & 0.268 \\
\hline Male $\mathrm{HOH}$ & $80(227)$ & 85 (109) & 0.259 \\
\hline $\begin{array}{l}\mathrm{HOH} \text { is subsistence } \\
\text { farmer }\end{array}$ & $71(200)$ & $82(101)$ & 0.031 \\
\hline $\begin{array}{l}\mathrm{HOH} \text { has no formal } \\
\text { education }\end{array}$ & $51(145)$ & $36(45)$ & 0.003 \\
\hline $\begin{array}{l}\text { Mother has no formal } \\
\text { education }\end{array}$ & $81(200)$ & $60(69)$ & $<0.001$ \\
\hline Muslim religion & $95(268)$ & $41(52)$ & $<0.001$ \\
\hline House quality score $=0$ & 73 (199) & $76(91)$ & 0.273 \\
\hline Toilet facility $=$ pit latrine & $82(231)$ & 74 (93) & 0.096 \\
\hline
\end{tabular}

$\mathrm{HOH}-$ head of household.

* Data are expressed as median (first, third quartile) or as \% $(n)$.

†Test for significance of differences in percentages by Pearson chi-square test.

stiff maize-based porridge nsima (48 vs. 54\%, $P=0.001$ ) In contrast, intakes of fish and beverages - specifically thobwa, a fermented maize beverage ( 578 vs. $492 \mathrm{~g} \mathrm{day}^{-1}$, $P<0.001$; data not shown) - were all higher in the intervention than in the control diets (Table 5). Some notable differences in food sources of iron and zinc also existed; proportions contributed by maize-based staples ( 46 vs. $50 \%$ iron; 46 vs. $55 \%$ zinc) and fish (13 vs. $10 \%$ iron; 26 vs. $21 \%$ zinc) were smaller and larger, respectively, in intervention than in control diets

Table 6 presents the median daily intakes of energy, nutrients and antinutrients. Intakes of phytate were lower, but intakes of protein, fat and percentage of energy from fat were higher in the intervention than in the control group $(P<0.01)$. A similar pattern was shown for intakes of vitamin $B_{12}$, calcium and zinc (primarily from small fish eaten whole with bones), whereas no differences for intakes of iron, vitamins $\mathrm{A}$ and $\mathrm{C}$, and folate were found.

Dietary quality indicators are shown in Table 7 . Intervention children consumed more diverse diets ( 6 vs. 5 different foods per day, $P<0.001$ ), with a higher proportion of their energy (as \%) and protein $\left(\mathrm{g} \mathrm{day}^{-1}\right)$ intake contributed by animal sources compared with the controls. As a consequence, densities for protein and vitamin $\mathrm{B}_{12}$, but not for zinc, iron or vitamin $\mathrm{A}$, were also higher for the intervention diets. Intakes of available zinc $\left(\mathrm{mgday}{ }^{-1}\right)$, but not available iron, followed a similar trend. In contrast, intervention children had diets with lower median phytate/zinc and phytate/iron molar ratios, and fewer phytate/zinc molar ratios above 15, than controls $(P<0.05)^{36,38}$.

\section{Comparison of predicted prevalence of inadequate intakes}

Intervention children had a lower risk of inadequate intakes for all nutrients examined, with differences reaching statistical significance for protein, folate, vitamin $\mathrm{B}_{12}$, calcium and zinc (Table 8). For energy, fewer intervention than control children had intakes less than two-thirds of the Food and Agriculture Organization (FAO)/World Health Organization (WHO)/United Nations University (UNU) ${ }^{33}$ average requirement (14 vs. 36\%, $P<0.01$; data not shown). Several investigators have suggested that the $\mathrm{FAO} / \mathrm{WHO} / \mathrm{UNU}$ requirements for energy for children may be too high ${ }^{39}$. If this is indeed the case, more children may have had acceptable energy intakes.

\section{Discussion}

In the present study we have compared the nutrient adequacy of the diets of children from households receiving a 6-month dietary intervention with that of controls by assessing indicators of dietary quality and the risk of inadequate nutrient intakes using the probability approach $^{21}$. We recognise that these results must be interpreted in light of the limitations of the quasiexperimental post-test design employed here. However, the participatory approach utilised for this community study and the nature of the dietary interventions precluded the use of a double-blind randomised controlled design.

\section{Indicators of dietary quality}

Children from the intervention households had diets at the end of the study that were more diverse and of better quality than the controls. Specifically, both their intake of animal protein (Table 5) and its contribution to energy

Table 3 Comparison of baseline and 1-year knowledge scores* within the intervention and control groups

\begin{tabular}{|c|c|c|c|c|c|c|}
\hline \multirow[b]{2}{*}{ Question } & \multicolumn{2}{|c|}{$\begin{array}{l}\text { Intervention } \\
\quad(n=227)\end{array}$} & \multirow[b]{2}{*}{$P+$} & \multicolumn{2}{|c|}{ Control $(n=83)$} & \multirow[b]{2}{*}{$P+$} \\
\hline & Baseline & 1-year & & Baseline & 1-year & \\
\hline Knowledge of Tulimbe processing methods - soaking, fermentation, etc. & $33(74)$ & $58(129)$ & $<0.001$ & $48(40)$ & $67(54)$ & 0.028 \\
\hline Knowledge of the nutritional importance of iron & $12(28)$ & $60(135)$ & $<0.001$ & $8(7)$ & $8(7)$ & 1.000 \\
\hline Knowledge of food sources for iron & $35(78)$ & $50(107)$ & 0.002 & $35(29)$ & $36(28)$ & 1.000 \\
\hline Knowledge of the nutritional importance of vitamin A & $45(103)$ & $84(188)$ & $<0.001$ & $45(37)$ & $74(61)$ & $<0.001$ \\
\hline Knowledge of food sources for vitamin $A$ & $35(78)$ & $32(71)$ & 0.679 & $22(18)$ & $22(18)$ & 1.000 \\
\hline
\end{tabular}

* Data are expressed as \% $(n)$.

† Within-group two-sided McNemar test of significance. 
Table 4 Baseline and 1-year practices* in the intervention and control groups

\begin{tabular}{|c|c|c|c|c|c|c|}
\hline \multirow[b]{2}{*}{ Question } & \multicolumn{2}{|c|}{ Intervention $(n=227)$} & \multirow[b]{2}{*}{$P \dagger$} & \multicolumn{2}{|c|}{ Control $(n=83)$} & \multirow[b]{2}{*}{$P \dagger$} \\
\hline & Baseline & 1-year & & Baseline & 1-year & \\
\hline \multicolumn{7}{|l|}{ Dietary diversification } \\
\hline Do you eat fish? & $2(5)$ & $84(186)$ & $<0.001$ & $6(5)$ & $82(68)$ & $<0.001$ \\
\hline Do you eat groundnut flour? & $92(208)$ & $93(204)$ & 0.608 & $91(74)$ & $92(74)$ & 1.000 \\
\hline Have your children eaten oil? & $39(87)$ & 66 (138) & $<0.001$ & $41(33)$ & $65(53)$ & 0.019 \\
\hline Do you know how to prepare soya? & $28(61)$ & $80(171)$ & $<0.001$ & $24(19)$ & $70(55)$ & $<0.001$ \\
\hline Do you prepare sunflower seeds? & $5(11)$ & $61(114)$ & $<0.001$ & $5(4)$ & $59(39)$ & $<0.001$ \\
\hline Do you dry vegetables? & 78 (177) & $80(176)$ & 0.738 & $83(68)$ & 77 (64) & 0.557 \\
\hline Do you dry fruit? & $12(28)$ & $24(52)$ & 0.002 & $16(13)$ & $29(24)$ & 0.090 \\
\hline \multicolumn{7}{|l|}{ Dietary modification } \\
\hline Do you soak whole maize kernels? & $15(33)$ & $58(129)$ & $<0.001$ & $23(19)$ & $52(43)$ & $<0.001$ \\
\hline Do you soak maize flour? & $3(7)$ & 47 (103) & $<0.001$ & $2(2)$ & $36(30)$ & $<0.001$ \\
\hline Do you soak beans? & $11(24)$ & 60 (133) & $<0.001$ & $13(11)$ & $52(43)$ & $<0.001$ \\
\hline Do you ferment flour? & $2(5)$ & $56(124)$ & $<0.001$ & $4(3)$ & $1(1)$ & 0.625 \\
\hline Do you use Tulimbe practices? & $35(77)$ & $81(170)$ & $<0.001$ & $32(25)$ & $71(57)$ & $<0.001$ \\
\hline
\end{tabular}

${ }^{*}$ Data are expressed as \% $(n)$.

†Within-group two-sided McNemar test of significance.

intake (Table 7) were higher, reflecting the adoption of our recommendation to increase intakes of flesh foods. Such an increase in the consumption of flesh foods is important. In the Human Nutrition Collaborative Research Support Programme, animal-source food was the single factor consistently identified to be positively associated with early childhood growth $^{2,40}$ and cognitive development ${ }^{41,42}$.

In the present study, because of the proximity of Lake Malawi, fresh or dried soft-boned fish, eaten whole with bones, was the animal-source food consumed most frequently and in the greatest amount (Table 5), providing a good source of readily absorbable calcium, zinc and some haem iron, especially for the intervention group ${ }^{43}$. Consumption of meat and poultry was constrained by cost and thus very low, so that it contributed only about $2 \%$ of the dietary iron in both groups. Nevertheless, even small amounts of meat, poultry and fish promote non-haem iron and zinc absorption, although the magnitude and mechanism of these effects in different types of meals remain uncertain ${ }^{44-47}$.

In contrast, the traditional Malawian maize-based staples, specifically the stiff maize porridge nsima,

Table 5 Comparison of food group intakes ${ }^{*}\left(\mathrm{~g} \mathrm{day}^{-1}\right)$ of the intervention and control groups post intervention

\begin{tabular}{lccr}
\hline Food group & $\begin{array}{c}\text { Intervention } \\
(n=200)\end{array}$ & $\begin{array}{c}\text { Control } \\
(n=81)\end{array}$ & $P+$ \\
\hline Maize-based staples & $727(565,935)$ & $704(578,899)$ & 0.569 \\
Other starchy staples & $152(94,270)$ & $156(114,248)$ & 0.619 \\
Nuts, seeds, beans & $66(44,100)$ & $70(47,109)$ & 0.664 \\
Fruits & $208(129,337)$ & $256(88,395)$ & 0.449 \\
Vegetables & $130(75,219)$ & $111(74,162)$ & 0.111 \\
Dairy and eggs & $26(26,51)$ & $32(26,48)$ & 0.659 \\
Meat, poultry \& insects & $15(4,35)$ & $3(2,12)$ & 0.059 \\
Fish & $62(39,88)$ & $48(29,74)$ & 0.010 \\
Sugars, sweets & $16(10,47)$ & $15(8,36)$ & 0.216 \\
Beverages & $595(494,725)$ & $496(379,621)$ & $<0.001$
\end{tabular}

* Data are expressed as median (first, third quartile).

† Probability of the difference being significant (Kruskal-Wallis test). contributed less dietary energy for intervention than for control children (Fig. 2), despite comparable intakes based on grams per day. This suggests that animal-source foods did not displace maize, or indeed intake of any other food group (Table 5), but instead provided much needed additional sources of vitamin $\mathrm{B}_{12}$, calcium, zinc, haem iron, retinol and fat for the intervention group (Table 6).

Several of our dietary strategies focused on reducing the level of hexa- and penta-inositol phosphates, strong antagonists of non-haem iron and zinc absorption ${ }^{44,48-50}$, in unrefined maize-based Malawian staples. Of these, the strategies that were most widely practised, and probably the most effective, involved soaking, and to a lesser extent fermenting, maize prior to preparing it as nsima or phala (Table 4). Our laboratory work has shown that more than $50 \%$ of the hexa- and penta-inositol phosphate content can be removed after soaking unrefined white Malawian

Table 6 Daily intakes* of energy, nutrients and antinutrients of the intervention and control groups post intervention

\begin{tabular}{lccr}
\hline Nutrient & $\begin{array}{c}\text { Intervention } \\
(n=200)\end{array}$ & $\begin{array}{c}\text { Control } \\
(n=81)\end{array}$ & \multicolumn{1}{c}{$P+$} \\
\hline Energy (kJ) & $5071(4092,6075)$ & $4686(3356,5665)$ & 0.002 \\
Protein (g) & $33(27,42)$ & $28(22,37)$ & $<0.001$ \\
Utilisable protein $(\mathrm{g})$ & $26(20,32)$ & $20(14,28)$ & $<0.001$ \\
Fat (g) & $14(10,22)$ & $9(7,14)$ & $<0.001$ \\
$\%$ Energy from fat & $11(8,15)$ & $9(7,11)$ & $<0.001$ \\
Vitamin A (RE) & $916(454,1461)$ & $914(398,1602)$ & 0.869 \\
Folate $(\mu \mathrm{g})$ & $172(139,231)$ & $173(132,234)$ & 0.433 \\
Vitamin $\mathrm{B}_{12}(\mu \mathrm{g})$ & $1.2(0.6,1.9)$ & $0.8(0.3,1.3)$ & $<0.001$ \\
Vitamin C (mg) & $118(78,176)$ & $129(66,171)$ & 0.856 \\
Calcium (mg) & $421(289,579)$ & $318(221,469)$ & 0.002 \\
Iron (mg) & $9.4(6.8,12.0)$ & $9.6(6.5,12.2)$ & 0.889 \\
Zinc $(\mathrm{mg})$ & $6.6(5.1,8.7)$ & $6.0(4.5,7.3)$ & 0.042 \\
Dietary fibre $(\mathrm{g})$ & $24(19,30)$ & $24(18,31)$ & 0.732 \\
Phytate $(\mathrm{mg}) \mp$ & $638(466,870)$ & $812(502,1170)$ & 0.007 \\
\hline
\end{tabular}

$\mathrm{RE}$ - retinol equivalents.

*Data are expressed as median (first, third quartile).

† Probability of the difference being significant (Kruskal-Wallis test).

$\ddagger$ For subjects adopting phytate reduction practices, phytate intakes were based on an estimated $50 \%$ reduction of phytate in maize-based staples. 


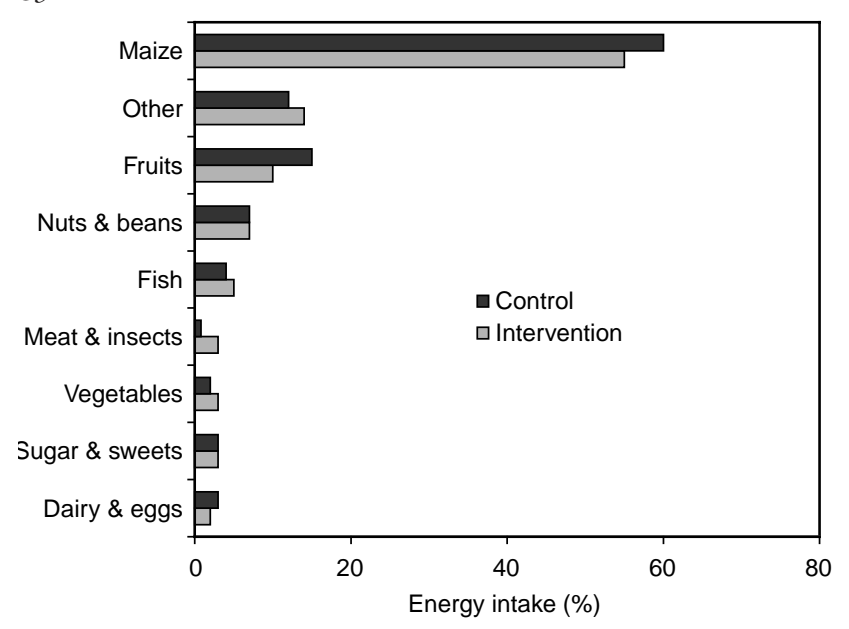

Fig. 2 Contribution of major food groups to energy intake

maize flour for $1 \mathrm{~h}$ and decanting off the excess water ${ }^{32}$. This loss occurs predominantly by passive diffusion of the water-soluble sodium, potassium or magnesium phytate that occurs in maize, mainly in the germ ${ }^{51,52}$. Natural lactic fermentation of maize flour slurries or porridges with or without the addition of germinated flour can also reduce their hexa- and penta-inositol phosphate content by hydrolysis to lower inositol phosphates that have no or very little inhibitory effect on zinc and iron absorption $^{48-50}$. The magnitude of the phytate reduction varies, depending on the conditions used ${ }^{32}$, ranging from $30 \%$ to more than $60 \%$ in maize. Enzyme hydrolysis is induced by microbial (EC3.1.3.8) and to a lesser extent by cereal phytase (EC3.1.3.26) enzymes when germinated cereal flour with enhanced phytase activity is added ${ }^{19}$. It is noteworthy that microbial phytase continues to act even after the $\mathrm{pH}$ has fallen below 3.4, the level necessary for reducing the growth of diarrhoeal pathogens ${ }^{53}$.

In the present study, adoption of our phytate reduction strategies led to markedly lower intakes of phytate, and a correspondingly lower median phytate-to-zinc molar ratio in the diets of intervention than in control children, despite adoption of the soaking practices by some of the control households (Table 4). As a result, more intervention than control children had diets with phytate-to-zinc molar ratios below the critical value (i.e. <15) said to severely compromise zinc absorption ${ }^{38,54}$. In a Mexican study, phytate-to-zinc molar ratios of diets of both toddlers and school-aged children were negatively correlated with height $^{1,2}$, a relationship that was not apparent here, possibly because our Malawian children had such a narrow range in height (i.e. $105.4 \pm 9.6 \mathrm{~cm}$ ).

The lower intakes of dietary phytate were reflected in turn by the significantly higher intakes of available zinc of the intervention children compared with controls. We did not observe a similar finding for available iron intakes (Table 7). This discrepancy arose, in part, because the model $^{29}$ we used to calculate available iron intakes, unlike that for available zinc, does not consider the negative impact of inositol phosphates on non-haem iron absorption $^{48,49}$. Clearly, the lower phytate intakes of our intervention group would have led to some improvement in absorption of non-haem iron in the diets of the intervention group, by altering the balance between the dietary modifiers of iron absorption as well as zinc. Nevertheless, the magnitude of this latter effect is uncertain. Stable isotope studies of young adult US males fed maize-based tortillas ${ }^{55}$ or polenta ${ }^{56}$ have reported $49 \%$ and $78 \%$ increases in iron and zinc absorption in those consuming low-phytate tortillas or

Table 7 Daily dietary quality indicators* for the intervention and control groups post intervention

\begin{tabular}{|c|c|c|c|}
\hline Indicator & $\begin{array}{l}\text { Intervention } \\
(n=200)\end{array}$ & $\begin{array}{c}\text { Control } \\
(n=81)\end{array}$ & $P \dagger$ \\
\hline No. of different foods & $6(5,7)$ & $5(4,7)$ & $<0.001$ \\
\hline$\%$ Energy from animal sources & $5(3,8)$ & $3(2,5)$ & $<0.001$ \\
\hline Animal protein (g) & $8.9(5.1,12.7)$ & $5.1(2.9,9.0)$ & $<0.001$ \\
\hline Protein $\left(\mathrm{g} \mathrm{MJ}^{-1}\right)$ & $6.9(6.2,7.4)$ & $6.5(6.0,6.9)$ & 0.008 \\
\hline Vitamin $\mathrm{A}\left(\mathrm{RE} \mathrm{MJ}^{-1}\right)$ & $179(94,275)$ & $198(101,318)$ & 0.381 \\
\hline Vitamin $B_{12}\left(\mu \mathrm{g} \mathrm{MJ}^{-1}\right)$ & $0.24(0.12,0.36)$ & $0.17(0.07,0.31)$ & 0.002 \\
\hline Calcium $\left(\mathrm{mg} \mathrm{MJ}^{-1}\right)$ & $83(62,108)$ & $78(55,97)$ & 0.170 \\
\hline Iron $\left(\mathrm{mg} \mathrm{MJ}^{-1}\right)$ & $1.82(1.53,2.20)$ & $2.06(1.77,2.39)$ & 0.002 \\
\hline Zinc $\left(\mathrm{mg} \mathrm{MJ}^{-1}\right)$ & $1.31(1.05,1.65)$ & $1.36(1.10,1.63)$ & 0.445 \\
\hline Haem iron (mg) & $0.51(0.46,0.56)$ & $0.33(0.26,0.41)$ & $<0.001$ \\
\hline Available iron $(\mathrm{mg}) \ddagger$ & $1.0(0.6,1.3)$ & $0.9(0.7,1.2)$ & 0.777 \\
\hline Available zinc (basal) (mg)‡ & $3.2(2.3,4.1)$ & $2.3(1.7,3.0)$ & $<0.001$ \\
\hline Available zinc (normative) (mg)‡ & $2.8(2.1,3.6)$ & $2.1(1.6,2.7)$ & $<0.001$ \\
\hline Phytate/iron molar ratio $\neq$ & $9(8,12)$ & $11(9,14)$ & 0.006 \\
\hline Phytate/zinc molar ratio $\ddagger$ & $16(12,20)$ & $20(15,23)$ & $<0.001$ \\
\hline Phytate/zinc molar ratio $<15$ & $23 \%(47)$ & $12 \%(10)$ & $0.045 \S$ \\
\hline
\end{tabular}

$\mathrm{RE}$ - retinol equivalents.

${ }^{*}$ Data are expressed as median (first, third quartile).

†Probability of the difference being significant (Kruskal-Wallis test).

$\ddagger$ Available iron and zinc have been calculated taking into account enhancing and inhibiting dietary factors consumed during the same meal (see text).

$\S$ Probability of the difference being significant (Pearson chi-square test). 
Table 8 Predicted prevalence (\%) of inadequate intake of selected nutrients in the intervention and control groups post intervention

\begin{tabular}{lccc}
\hline Nutrient & $\begin{array}{c}\text { Intervention } \\
(n=200)\end{array}$ & $\begin{array}{c}\text { Control } \\
(n=81)\end{array}$ & $P^{*}$ \\
\hline Macronutrients & & & \\
Protein & & 7 & 0.004 \\
Vitamins & 7 & 5 & 0.467 \\
Vitamin A basal & 15 & 17 & 0.475 \\
Vitamin A normative & $<1$ & 2 & 0.003 \\
Folate & 23 & 41 & 0.001 \\
Vitamin B & 2 & 4 & 0.433 \\
Vitamin C & & & \\
Minerals & 34 & 54 & $<0.001$ \\
Calcium & 19 & 20 & 0.529 \\
Available iron & 10 & 15 & 0.001 \\
Available zinc basal & 26 & 44 & 0.002 \\
Available zinc normative & & & \\
\hline
\end{tabular}

* Probability of the difference being significant (Pearson chi-square test).

polenta, respectively, with levels of phytate reduction ranging from 35 to $63 \%$, compared with the $21 \%$ reduction reported here for our intervention group (Table 6).

The differences in diversity and quality of the diets of the intervention compared with the control children, described above, occurred despite the apparent spread of some of the intervention messages to the control villages (Table 3$)^{26}$. Such contamination has been described in other community-based studies ${ }^{57,58}$. We attempted to strike a balance between the control communities being sufficiently far away to prevent the spread of messages from the intervention households, yet remain comparable socio-economically and demographically ${ }^{59}$. However, in this study, we did not succeed in achieving this balance.

\section{Predicted prevalence of inadequate nutrient intakes}

The post-intervention children had a lower risk of inadequate intakes for protein, calcium, zinc and vitamin $\mathrm{B}_{12}$ than the controls (Table 8), attributed to a greater adoption of our dietary strategies, as discussed above. In contrast, risk of inadequate intakes for iron did not differ between the two groups, in part because fish rather than meat was the major source of haem iron and our estimates of iron bioavailability did not take into account the impact of our phytate reduction strategies ${ }^{29}$ in these rural Malawian diets.

In the Kenyan Nutrition Collaborative Research Support Program (NCRSP) study, toddlers and school-aged children had an even greater risk of inadequate intakes for calcium, zinc, vitamin $\mathrm{B}^{12}$ and iron ${ }^{2,60}$ than the levels reported here, even for our control group. Such a high prevalence of inadequate intakes for the Kenyan children was attributed mainly to their low intakes of energy per se and its small contribution from animal products (i.e. $8 \%)^{60,61}$.

In our study, risk of inadequate intakes of protein in both groups was very low, despite their small intakes of animal protein (Table 7). This finding is consistent with earlier dietary studies on African children from Malawi ${ }^{14}$ and Kenya $^{62}$. Likewise, risk of inadequate intakes of folate, vitamin $\mathrm{C}$ and vitamin A were low in both groups, as noted for the Kenyan toddlers ${ }^{61}$.

Failure to demonstrate any significant differences between groups for risk of inadequate intake for vitamin A is surprising (Table 8), because we provided the intervention households with papaya seedlings and solar dryers in an effort to ensure a more consistent year-round intake of provitamin A carotenoids. This may have arisen because at 1 year in both groups, the same proportion of households reportedly practised drying vegetables and fruits (Table 4), and only one of the dietary recall periods coincided with the papaya or mango season. Nevertheless, if the larger intake of fat by the intervention children is considered, their risk of inadequate vitamin A intakes may actually have been lower than the controls'. Certainly, several studies have highlighted that increases in dietary fat, especially when combined with anthelmintic treatment as practised here, enhances the bioavailability of carotenoids from green leaves and red sweet potatoes ${ }^{63-66}$.

It is noteworthy that the diets of our Malawian children were inadequate in more than one micronutrient. The most common combinations of deficits were those of calcium + iron + zinc, and the vitamins $\mathrm{A}+\mathrm{B}_{12}$, consistent with the NCRSP study ${ }^{67}$. Fewer intervention than control children had diets at risk of low intakes of more than one nutrient ( 23 vs. 39\%, $P<0.05$ ), based on a cut-off of at least an $85 \%$ probability of inadequacy. This finding is of significance in view of the results of several supplementation trials that have failed to demonstrate any positive growth response to a single micronutrient supplement ${ }^{68-73}$.

In conclusion, results indicate that careful selection of locally available foods combined with modifications to household food preparation and processing practices to reduce phytate intake, implemented using a participatory approach, can reduce simultaneously dietary inadequacies of protein, calcium, zinc and vitamin $\mathrm{B}_{12}$, even in rural households with very limited resources. Nevertheless, our findings highlight the importance of strategies to increase consumption of meat and poultry to ensure adequate intakes of readily available iron for Malawian children.

\section{Acknowledgements}

Special thanks to the people of the communities, and our co-investigator, Dr Nancy Drost, who implemented the intervention and oversaw the community development aspects of the project. Thanks also to our federal collaborators at the Ministries of Health, Agriculture and Community Services. Our Malawian programme staff (E Umar, C Kayira, the late W Makwenda, L Gonani and M Kulumunyu), field staff and our consultatory committee 
members from the Ministries of Health, Agriculture and Community Services and Save the Children US were crucial to the success of the programme. Thanks to SmithKline Beecham for donating the albendazole. The research was funded by the Canadian International Development Agency through the Micronutrient Initiative, UNICEF Malawi and World Vision Malawi.

\section{References}

1 Allen LH, Black AK, Backstrand JR, Pelto GH, Ely RD, Molina E, et al. An analytical approach for exploring the importance of dietary quality versus quantity in the growth of Mexican children. Food and Nutrition Bulletin 1991; 13: $95-104$.

2 Neumann CG, Harrison GG. Onset and evolution of stunting in infants and children. Examples from the Human Nutrition Collaborative Research Support Program. Kenya and Egypt studies. European Journal of Clinical Nutrition 1994; 48 S90-102.

3 Solomons NW, Ruz M, Gibson RS. Single-nutrient interventions with zinc. American Journal of Clinical Nutrition 1999; 70: $111-3$

4 Rosado JL, Lopez P, Munoz E, Martinez H, Allen LH. Zinc supplementation reduces morbidity, but neither zinc nor iron supplementation affects growth or body composition of Mexican preschoolers. American Journal of Clinical Nutrition 1997; 65: 13-29.

5 Gibson RS, Hotz C. Nutritional causes of linear growth faltering in infants during the complementary feeding period. In: Martorell R, Haschke F, eds. Nutrition and Growth. 47th Nestle Nutrition Workshop Series, Pediatric Program. Philadelphia, PA: Lippincott, Williams \& Wilkins, 2001; 159-96.

6 Gershoff SN, McGandy RB, Nondasuta A, Tantiwongse P. Nutrition studies in Thailand: effects of nutrient supplements, and health interventions on growth of preschool Thai village children. American Journal of Clinical Nutrition 1988; 48: 1214-8.

7 Cavan KR, Gibson RS, Grazioso CF, Isalguen AM, Ruz M, Solomons NW. Growth and body composition of periurban Guatemalan children in relation to zinc status: a longitudinal zinc intervention trial. American Journal of Clinical Nutrition 1993; 57: 344-52.

8 Lartey A, Mau A, Brown KH, Peerson JM, Dewey KG. A randomized, community-based trial of the effects of improved centrally processed complementary foods on growth and micronutrient status of Ghanaian infants from 6 to 12 mo of age. American Journal of Clinical Nutrition 1999; 70: 391-404

9 van Stuijvenberg ME, Kvalsvig JD, Faber M, Kruger M, Kenoyer DG, Spinnler Benade AJ. Effect of iron-, iodine-, and $\beta$-carotene-fortified biscuits on the micronutrient status of primary school children: a randomized controlled trial. American Journal of Clinical Nutrition 1999; 69: 497-503.

10 Thu BD, Schultink W, Dillon D, Gross R, Leswara ND, Khoi HH. Effect of daily and weekly micronutrient supplementation on micronutrient deficiencies and growth in young Vietnamese children. American Journal of Clinical Nutrition 1999; 69: 80-6.

11 Ramakrishnan U, Martorell R, Schroeder DG, Flores R. Role of intergenerational effects on linear growth. Journal of Nutrition 1999; 129: 544S-9S.

12 Gibson RS, Hotz C, Temple L, Yeudall F, Mtimuni B, Ferguson EL. Dietary strategies to combat deficiencies of iron, zinc, and vitamin A in developing countries: development, implementation, monitoring and evaluation. Food and Nutrition Bulletin 2000; 21: 219-31.
13 Ferguson EL, Gibson RS, Ounpuu S, Sabry J. The validity of the 24 hour recall for estimating the energy and selected nutrient intakes of a group of rural Malawian preschool children. Ecology of Food and Nutrition 1989; 23: 273-85.

14 Ferguson EL, Gibson RS, Opare-Obisaw C, Ounpuu S, Thompson LU, Lehrfeld J. The zinc nutriture of preschool children living in two African countries. Journal of Nutrition 1993; 123: 1487-96.

15 Ferguson EL, Gibson RS, Opare-Obisaw C, Osei-Opare F, Lamba C, Ounpuu S. Seasonal food consumption patterns and dietary diversity of rural preschool Ghanaian and Malawian children. Ecology of Food and Nutrition 1993; 29 219-34.

16 Ferguson EL, Gibson RS, Opare-Obisaw C, Ounpuu S, Lamba C. Dietary strategies for improving the zinc nutriture of rural, southern Malawian and Ghanaian children. Ecology of Food and Nutrition 1995; 34: 33-47.

17 Huddle J-M, Gibson RS. Sub-optimal zinc status in pregnant Malawian women: its association with low intakes of poorly available zinc, frequent reproductive cycling, and malaria. American Journal of Clinical Nutrition 1998; 67: 702-9.

18 Ferguson EL, Gadowsky SL, Huddle JM, Cullinan TR, Lehrfeld J, Gibson RS. An interactive 24-h recall technique for assessing the adequacy of trace mineral intakes of rural Malawian women; its advantages and limitations. European Journal of Clinical Nutrition 1995; 49: 565-78.

19 Gibson RS, Ferguson EL. Nutrition intervention strategies to combat zinc deficiency in developing countries. Nutrition Research Reviews 1998; 11: 115-31.

20 Gibson RS, Yeudall F, Drost N, Mtimuni B, Cullinan T. Dietary interventions to prevent zinc deficiency. American Journal of Clinical Nutrition 1998; 68: 484S-7S.

21 National Research Council. Nutrient Adequacy: Assessment using Food Consumption Surveys. Washington, DC: National Academy Press, 1986.

22 National Statistical Office (NSO). Malawi Demographic and Health Survey. Zomba, Malawi: NSO, 1994.

23 Vundule C, Mharakurwa S. Knowledge, practices and perceptions about malaria in rural communities of Zimbabwe: relevance to malaria control. Bulletin of the World Health Organization 1996; 74(1): 55-60.

24 Yeudall F, Gibson RS, Kayira C, Umar E. Efficacy of a multimicronutrient dietary intervention based on haemoglobin, hair zinc concentrations, and selected functional outcomes in rural Malawian children. European Journal of Clinical Nutrition 2002; 56: 1176-85.

25 National Statistical Office (NSO)/Macro International Inc (MII). Malawi Knowledge, Attitudes and Practices in Health Survey 1996. Zomba, Malawi and Calverton, MD: NSO/MII, 1996.

26 Drost NM. Transforming social, gendered practices affecting malnutrition: action research in Malawi. DEd thesis, University of Toronto, Canada, 1998.

27 Gibson RS, Ferguson EL. An Interactive 24-bour Recall for Assessing the Adequacy of Iron and Zinc Intakes in Developing Countries. Washington, DC: International Life Sciences Institute, 1999.

28 Hotz C. Assessment and improvement of complementary diets in rural Malawi, with a special focus on zinc. PhD thesis, University of Otago, New Zealand, 2000.

29 Bunch S, Murphy SP. User's Guide to the Operation of the WorldFood Dietary Assessment System, Version 2.0. Berkeley, CA: Office of Technology Licensing, University of California, Berkeley, 1997.

30 Ferguson EL, Gibson R, Opare-Obisaw C, Ounpuu S, Thompson LU, Lehrfeld J. The zinc, calcium, copper, manganese, nonstarch polysaccharide and phytate content of seventy-eight locally grown and prepared African foods. Journal of Food Composition and Analysis 1993; 6: $87-99$. 
31 Hatloy A, Torheim L, Oshaug A. Food variety - a good indicator of nutritional adequacy of the diet? A case study from an urban area in Mali, West Africa. European Journal of Clinical Nutrition 1998; 52: 891-8.

32 Hotz C, Gibson RS. Assessment of home-based processing methods to reduce the phytate content and phytate/zinc molar ratios of white maize (Zea mays). Journal of Agricultural and Food Chemistry 2001; 49: 692-8.

33 Food and Agriculture Organization/World Health Organization (WHO)/United Nations University. Energy and Protein Requirements. WHO Technical Report Series No. 724. Geneva: WHO, 1985.

34 Food and Agriculture Organization (FAO)/World Health Organization. Calcium Requirements. Nutrition Reports Series No. 30. Rome: FAO, 1962.

35 Food and Agriculture Organization (FAO)/World Health Organization. Requirements of Vitamin A, Iron, Folate, and Vitamin B-12. FAO Nutrition Meetings Report Series No. 23. Rome: FAO, 1988.

36 World Health Organization (WHO). Trace Elements in Human Nutrition and Health. Geneva: WHO, 1996.

37 SPSS, Inc. SPSS for Windows, Version 9.0. Chicago, IL: SPSS Inc., 2000.

38 Turnlund JR, King JC, Keyes WR, Gong B, Michel MC. A stable isotope study of zinc absorption in young men: effects of phytate and $\alpha$-cellulose. American Journal of Clinical Nutrition 1984; 40: 1071-7.

39 Goran M, Poehlman E, Johnson R. Energy requirements across the life span: new findings based on measurement of total energy expenditure with doubly labeled water. Nutrition Research 1995; 15: 115-50.

40 Allen LH, Backstrand JR, Stanek EJ 3rd, Pelto GH, Chavez A, Molina E, et al. The interactive effects of dietary quality on the growth and attained size of young Mexican children. American Journal of Clinical Nutrition 1992; 56: 353-64.

41 Kirksey A, Rahmanifar A, Wachs TD, McCabe GP, Bassily NS, Bishry Z, et al. Determinants of pregnancy outcome and newborn behavior of a semirural Egyptian population. American Journal of Clinical Nutrition 1991; 54: 657-67.

42 Sigman M, Neumann CG, Baksh M, Bwibo N, McDonald MA. Relation between nutrition and development in Kenyan toddlers. Journal of Pediatrics 1989; 115: 357-64.

43 Hansen M, Thilsted S, Sandstrom B, Kongsbak K, Larsen T, Jensen $\mathrm{M}$, et al. Calcium absorption from small soft-boned fish. Journal of Trace Elements in Medicine and Biology 1998; 12: 148-54.

44 Hallberg L, Hulthen L. Prediction of dietary iron absorption: an algorithm for calculating absorption and bioavailability of dietary iron. American Journal of Clinical Nutrition 2000; 71: $1137-60$.

45 Reddy MB, Hurrell RF, Juillerat MA, Cook JD. The influence of different protein sources on phytate inhibition of nonheme-iron absorption in humans. American Journal of Clinical Nutrition 1996; 63: 203-7.

46 Snedeker S, Greger J. Metabolism of zinc, copper and iron as affected by dietary protein, cysteine and histidine. Journal of Nutrition 1983; 119: 644-52.

47 Sandström B, Almgren A, Kivisto B, Cederblad A. Effect of protein and protein source on zinc absorption in humans. Journal of Nutrition 1989; 119: 48-53.

48 Brune M, Rossander-Hulten L, Hallberg L, Gleerup A, Sandberg AS. Iron absorption from bread in humans: inhibiting effects of cereal fiber, phytate and inositol phosphates with different numbers of phosphate groups. Journal of Nutrition 1992; 122: 442-9.

49 Sandberg A-S, Brune M, Carlsson N-G, Hallberg L, Skoglund E, Rossander-Hulthen L. Inositol phosphates with different numbers of phosphate groups influence iron absorption in humans. American Journal of Clinical Nutrition 1999; 70 : 240-6.

50 Lönnerdal B, Sandberg A, Sandström B, Lunz C. Inhibitory effects of phytic acid and other inositol phosphates on zinc and calcium absorption in suckling rats. Journal of Nutrition 1989; 119: 211-4.

51 O'Dell BL, de Boland AR, Koirtyohann SR. Distribution of phytate and nutritionally important elements among morphological components of cereal grains. Journal of Agricultural and Food Chemistry 1972; 20: 718-21.

52 de Boland AR, Garner GB, O'Dell BL. Identification and properties of 'phytate' in cereal grains and oilseed products. Journal of Agricultural and Food Chemistry 1975; 23: 1186-9.

53 Lorri W, Svanberg U. Lower prevalence of diarrhea in young children using lactic acid-fermented cereal gruel. Food and Nutrition Bulletin 1993; 15: 57-63.

54 Morris E, Ellis R. Effect of dietary phytate/zinc molar ratio on growth and bone zinc response of rats fed semipurified diets. Journal of Nutrition 1980; 110: 1037-45.

55 Mendoza C, Viteri FE, Lönnerdal B, Young KA, Raboy V, Brown KH. Effect of genetically modified, low phytic acid maize on absorption of iron from tortillas. American Journal of Clinical Nutrition 1998; 68: 1123-7.

56 Adams C, Hambridge M, Raboy V, Dorsch JA, Sian L, Westcott JL, et al. Zinc absorption from a low-phytic acid maize. American Journal of Clinical Nutrition 2002; 76 : 556-9.

57 Bloem MW. Monitoring process and impact indicators of food-based strategies: a Bangladesh experience. In: Proceedings of Workshop on Prevention and Control of Micronutrient Malnutrition through Food-based Actions in the SAARC Countries. Dhaka: Bangladesh Agricultural Research Council, 1997; 98-107.

58 Kidala D, Greiner T, Gebre-Medhin M. Five-year follow-up of a food-based vitamin A intervention in Tanzania. Public Health Nutrition 2000; 3: 425-31.

59 de Pee S, West C. Dietary carotenoids and their role in combating vitamin A deficiency: a review of the literature. European Journal of Clinical Nutrition 1996; 50(Suppl. 3): S38-53.

60 Murphy S, Beaton G, Calloway D. Estimated mineral intakes of toddlers: predicted prevalence of inadequacy in village populations in Egypt, Kenya, and Mexico. American Journal of Clinical Nutrition 1992; 56: 565-72.

61 Calloway D, Murphy S, Beaton G, Lein D. Estimated vitamin intakes of toddlers: predicted prevalence of inadequacy in village populations in Egypt, Kenya and Mexico. American Journal of Clinical Nutrition 1993; 58: 376-84.

62 Beaton GH, Calloway DH, Murphy SP. Estimated protein intakes of toddlers: predicted prevalence of inadequate intakes in village populations in Egypt, Kenya and Mexico. American Journal of Clinical Nutrition 1992; 55: 902-11.

63 Jayarajan P, Reddy V, Mohanram M. Effect of dietary fat on absorption of beta carotene from green leafy vegetables in children. Indian Journal of Medical Research 1980; 71: 53-6.

64 Erdman JW, Bierer TL, Gugger ET. Absorption and transport of carotenoids. Annals of the New York Academy of Sciences 1993; 691: 76-85.

65 Jalal F, Nesheim MC, Agus Z, Sanjur D, Habicht JP. Serum retinol concentrations in children are affected by food sources of $\beta$-carotene, fat intake, and anthelmintic drug treatment. American Journal of Clinical Nutrition 1998; 68: 623-9.

66 Takyi EEK. Children's consumption of dark green, leafy vegetables with added fat enhances serum retinol. Journal of Nutrition 1999; 129: 1549-54.

67 Calloway DH. Human Nutrition: Food and Micronutrient Relationships. Discussion Paper No. 1. Washington, DC: International Food Policy Research Institute, 1995. 
68 Bates C, Evans P, Dardenne M, Prentice A, Lunn PG, Northrop-Clewes CA, et al. A trial of zinc supplementation in young rural Gambian children. British Journal of Nutrition 1993; 69: 243-55.

69 Kikafunda JK, Walker AF, Allan EF, Tumwine JK. Effect of zinc supplementation on growth and body composition of Ugandan preschool children: a randomized, controlled, intervention trial. American Journal of Clinical Nutrition 1998; 68: 1261-6.

70 Friis $\mathrm{H}$, Ndhlovu $\mathrm{P}$, Nduluza T. The impact of zinc supplementation on growth and body composition: a randomized controlled trial among rural Zimbabwean school children. European Journal of Clinical Nutrition 1997; 51: 38-45.
71 Rahmathullah L, Underwood BA, Thulasiraj RD, Milton RC. Diarrhea, respiratory infections, and growth are not affected by a weekly low-dose vitamin A supplement: a masked, controlled field trial in children in southern India. American Journal of Clinical Nutrition 1991; 54: 568-77.

72 Rosado JL. Separate and joint effects of micronutrient deficiencies on linear growth. Journal of Nutrition 1999; 129: 531S-3S.

73 Bahl R, Bhandari N, Taneja S, Bhan M. The impact of vitamin A supplementation on physical growth of children is dependent on season. European Journal of Clinical Nutrition 1997; 51: 26-9. 